\title{
Pembuatan Minyak Biji Karet Dari Biji Karet Dengan Menggunakan Metode Screw Pressing: Analisis Produk Penghitungan Rendemen, Penentuan Kadar Air Minyak, Analisa Densitas, Analisa Viskositas, Analisa Angka Asam Dan Analisa Angka Penyabunan
}

\author{
Abdul Hakim dan Edwin Mukhtadi* \\ Program Studi Teknik Kimia, Departemen Teknologi Industri, Sekolah Vokasi, Universitas Diponegoro \\ Jl. Prof. Soedarto, Tembalang, Kota Semarang, Jawa Tengah 50275, Indonesia \\ Email: edwinmukhtadi@gmail.com
}

\begin{abstract}
Abstrak
Karet (Hevea brasiliensis Muell. Arg) merupakan salah satu hasil pertanian yang banyak menunjang perekonomian Negara. Selain menghasilkan lateks, perkebunan karet juga menghasilkan biji karet yang belum termanfaatkan secara optimum. Dengan melihat tingginya kandungan minyak di dalam daging biji karet yakni sebesar $45.63 \%$ maka minyak tersebut sangat potensial untuk dimanfaatkan. Proses pengambilan minyak biji karet dapat dilakukan dengan dua cara antara lain pengepresan (pressing), dan pelarut (solvent). Dua cara yang umum digunakan yaitu dengan metode pengepresan mekanis antara lain pengepresan hidrolik (hydraulic pressing) dan pengepresan berulir (screw pressing). Cara screw pressing memerlukan perlakuan pendahuluan yang terdiri dari proses pemanasan atau tempering. Pada penelitian ini mempelajari tentang "Pengaruh Ukuran Material dan Temperatur Pemanasan Awal terhadap Perolehan Minyak Biji Karet dengan Metode Pengepresan Berulir (screw pressing)". Biji karet dibersihkan dan disortir dari kulitnya maupun kotoran kemudian diperkecil ukuran biji karet dengan variasi ukuran $100 \mathrm{~mm}( \pm 10 \mathrm{~mm}), 50 \mathrm{~mm}( \pm$ $10 \mathrm{~mm}$ ) dan 100 mesh. Selanjutnya dipanaskan dengan variabel suhu $50^{\circ} \mathrm{C}, 60^{\circ} \mathrm{C}$ dan $70^{\circ} \mathrm{C}$ kemudian biji karet tersebut dipress dengan variabel kecepatan putar ulir 200 ppm. Hasil dari penelitian ini didapat persentase terbesar pada variasi ukuran material 100 mesh dan suhu pemanasan awal $70{ }^{\circ} \mathrm{C}$ yaitu sebesar $10,11 \%$. Kadar air 0,2 \%, densitas 0,920 gr/ml, dan viskositas 34,476 cp.
\end{abstract}

Kata kunci: Biji karet, Screw pressing, Minyak biji karet.

\author{
Abstract \\ Making Rubber Seed Oil From Rubber Bean With Using Screw Pressing Method: Product Analysis \\ Calculation of Rendement, Determination of Water Content of Oil, Density Analysis, Viscosity Analysis, \\ Analysis of Acid Numbers and Analysis of Plaque Rate
}

Rubber (Hevea brasiliensis Muell. Arg) is which one of agriculture product many have developing economic country. Except of latex product, rubber of plantation to production rubber seeds to optimum used not yet. As see oil content on rubber seed is very high $45,63 \%$ so the rubber seed oil has wide potential aplication. To obtain oil from rubber seed, there are two methods commonly used for oil extraction from rubber seeds, which are mechanical pressing and solvent extraction. Two common methods of mechanical pressing can be used, which are hydraulic pressing and screw pressing. Screw pressing methode had been pretreatment consist of tempering. The objective of this research is to study the "effect of material size and preheating temperature on rubber seed oil yield using screw pressing methode. The rubber seeds are cleaned and the kernels are separated manually from the seeds. after that, rubber seed was size reducted with various $100 \mathrm{~mm}( \pm 10 \mathrm{~mm}), 50 \mathrm{~mm}$ 
$( \pm 10 \mathrm{~mm})$ and 100 mesh after that the rubber seeds preheatead with various temperatures $50^{\circ} \mathrm{C}, 60^{\circ} \mathrm{C}$ and $70^{\circ} \mathrm{C}$. The next step is the pressing operation using screw speed $200 \mathrm{rpm}$. The higher result from research had oil yield persentation $10,11 \%$ with variations material size at 100 mesh and preheating temperature $70^{\circ} \mathrm{C}$.moisture content $0,2 \%$, density $0,920 \mathrm{gr} / \mathrm{ml}$, and viscosity $34,476 \mathrm{cp}$.

Keywords: Rubber seed, Screw pressing, Rubber seed oil.

\section{PENDAHULUAN}

Indonesia merupakan salah satu negara penghasil karet terbesar di dunia dengan total produksi pada tahun 2007 mencapai 2,55 juta ton/tahun. Luas seluruh area perkebunan karet di Indonesia mencapai 3,4 juta hektar yang merupakan luas area perkebunan karet terbesar di dunia. Dalam industri karet, hasil utama yang diambil dari tanaman karet adalah latex. Sementara itu biji karet masih belum dimanfaatkan dan dibuang sebagai limbah.

Tanaman karet dapat menghasilkan 800 biji karet untuk setiap pohonnya per tahun. Pada lahan seluas 1 hektar, dapat ditanami sebanyak 400 pohon karet. Maka untuk lahan seluas 1 hektar diperkirakan dapat menghasilkan $5.050 \mathrm{~kg}$ biji karet per tahunnya (Siahaan, et al., 2011).

Biji karet mengandung sekitar 40-50\%-b minyak nabati dengan komposisi asam lemak yang dominan adalah asam oleat dan asam linoleat, sementara sisanya berupa asam palmitat, asam stearat, asam arachidat dan asam lemak lainnya (Setyawardhani et al., 2010).

Sayangnya, pemanfaatan biji karet di Indonesia belum mendapat perhatian lebih. Biji karet dapat dimanfaatkan sebagai biodiesel dengan melalui beberapa proses yaitu ekstraksi minyak biji karet, pemurnian minyak, transesterifikasi, pencucian dan pengeringan. Pada penelitian ini berisi tentang mendapatkan minyak biji karet dengan cara pengepresan berulir (screw press). Efisiensi pengepresan bergantung pada jenis biji, kadar air umpan, pemasakan, tekanan, dan temperatur pengepresan. Umpan seringkali mengalami pemanggangan terlebih dahulu sebelum di-press. Tujuan utama pemanggangan adalah membuat dinding sel permeabel dan menurunkan viskositas minyak sehingga dapat mempermudah minyak keluar. Pemanasan dilakukan dengan tetap menjaga kelembaban bahan. Selain itu, pemanggangan dapat mensterilkan biji dari bakteri, jamur, dan mikroorganisme lain. Overcooking yang terjadi pada saat pemanggangan dapat mengakibatkan kerusakan pada dinding sel sehingga menghalangi difusi minyak keluar. Selain itu, pemanggangan yang terlalu lama atau terlalu tinggi temperaturnya dapat mengakibatkan kerusakan produk maupun cake sisa pengepresan (Hidlich, 1949). Oleh karena itulah, penelitian ini berisi tentang cara memperoleh minyak biji karet dengan maksimal menggunakan metode penekanan mekanik, dengan variabel yang di amati ukuran partikel material dan temperatur pemanasan awal. Buah karet berbentuk kotak tiga atau empat. Setelah berumur enam bulan buah akan masak dan pecah sehingga biji karet terlepas dari batoknya. Biji karet mempunyai bentuk ellipsoidal, dengan panjang 2,5-3 cm, yang mempunyai berat 2-4 gram/biji. Biji karet terdiri dari $40-50 \%$ kulit yang keras berwarna coklat, dan 50-60\% kernel yang berwarna putih kekuningan. Kernel biji karet terdiri dari 45,63\% minyak, 2,71\% abu, $3,71 \%$ air, $22,17 \%$ protein dan $24,21 \%$ karbohidrat, sehingga biji karet berpotensi digunakan sebagai sumber minyak. Kandungan air yang besar dalam biji karet memicu hidrolisis trigliserida menjadi asam lemak. Maka biji karet dikeringkan dan dipres untuk diambil minyaknya (Ikwuagwu et al., 2000). Komposisi asam lemak dalam minyak biji karet dapat dilihat pada Tabel 1.

Tabel 1. Komposisi Asam Lemak dalam Minyak Biji Karet. (Setyawardhani et al., 2010).

\begin{tabular}{cc}
\hline Komposisi & Persentase $(\%-b)$ \\
\hline Asam palmitat & 13,11 \\
Asam stearate & 12,66 \\
Asam arachidat & 0,54 \\
Asam oleat & 39,45 \\
Asam linoleate & 33,12 \\
Asam lemak lainnya & 1,12 \\
\hline
\end{tabular}


Asam oleat, linoleat dan linolenat sangat bermanfaat bagi kesehatan, sebagai sumber asam lemak omega 3, 6 dan 9, sedangkan asam palmitat dan stearat berpotensi untuk dijadikan bahan bakar biodiesel berkualitas baik. Asamasam lemak dalam biji karet dapat diperoleh dengan hidrolisis terhadap minyaknya. Asamasam lemak jenuh (palmitat, stearat dan arachidat) dapat dipisahkan dari asam lemak tak jenuhnya (oleat dan linoleat) dengan chilling (Setyawardhani et al., 2007).

Pada umumnya minyak tersusun atas tiga molekul asam lemak yang bersenyawa dengan satu molekul gliserin, sehingga sering disebut dengan trigliserida. Suatu trigliserida dapat mengandung hanya satu macam asam lemak atau dua sampai tiga macam asam lemak. Minyak dapat berasal dari hewan dan tumbuhan, minyak yang diambil dari tumbuhan dinamakan minyak nabati.

Biji karet masak terdiri dari $70 \%$ kulit buah dan $30 \%$ biji karet. Biji karet terdiri dari $\pm 40 \%$ tempurung dan 60\% tempurung daging biji, dimana variasi proporsi kulit dan daging buah tergantung pada kesegaran biji. Biji karet yang segar memiliki kadar minyak yang tinggi dan kandungan air yang rendah. Akan tetapi biji karet yang terlalu lama disimpan akan mengandung kadar air yang tinggi sehingga menghasilkan minyak dengan mutu yang kurang baik. Biji segar terdiri dari $34,1 \%$ kulit, $41,2 \%$ isi dan $24,4 \%$ air, sedangkan pada biji karet yang telah dijemur selama dua hari terdiri dari 41,6\% kulit, $8 \%$ air, $15,3 \%$ minyak dan $35,1 \%$ bahan kering. Biji karet mengandung $40 \%$ sampai $50 \%$ minyak yang terdiri dari $17 \%$ sampai dengan $22 \%$ asam lemak jenuh dan $77 \%$ sampai dengan $82 \%$ asam lemak tak jenuh (Swern, 1964).

Mutu minyak yang berasal dari biji-bijian khususnya biji karet dipengaruhi oleh beberapa faktor, yaitu (Larrañaga et al., 2016):

1. Kualitas dan kemurnian bahan baku. Adanya bahan asing atau biji yang berkualitas jelek yang tercampur dalam bahan baku pada proses, akan menyebabkan minyak cepat rusak dan berbau.

2. Usia biji. Biji karet yang usianya cukup tua akan menghasilkan minyak yang lebih baik kuantitas dan kualitasnya dibanding dengan biji karet yang lebih muda.
3. Kadar air yang terkandung dalam biji karet. Biji karet yang terlalu lama disimpan akan mengandung kadar air yang tinggi, sehingga dapat menghasilkan minyak dengan mutu yang kurang baik.

4. Perlakuan terhadap bahan baku pada saat proses dan pasca-proses (misalnya: halusnya hasil pencacahan yang dilakukan, pemilihan jenis pelarut, penyimpanan minyak hasil proses, dan sebagainya).

Pemanfaatan minyak biji karet dalam berbagai industri lebih lanjut ditentukan oleh sifat fisika dan kimiannya. Berikut ditampilkan hasil analisis karakteristik rninyak biji karet mentah pada Tabel 2.

Tabel 2. Karakteristik Minyak Biji Karet ((Baskaran, 1980)

\begin{tabular}{ll}
\hline Karakteristik & Nilai \\
\hline Nilai Saponifikasi & $187,6-191,4$ \\
Bilangan iod & $133,8-146,6$ \\
Indeks Reflaksi & $1,4743-1,4749$ \\
Spesifik Gravity & $0,925-0,929$ \\
Persen Bilangan tak & $0,6-1,0$ \\
tersabunkan & \\
\hline
\end{tabular}

Tujuan dari penelitian ini adalah untuk mengetahui rendemen dan yield minyak biji karet yang dihasilkan dari variabel yang telah ditentukan, sifat fisik minyak biji karet yang dihasilkan dari variabel yang telah ditentukan, nilai bilangan asam dan bilangan penyabunan minyak biji karet yang dihasilkan dari variabel yang telah ditentukan, dan variabel optimum dalam pembuatan minyak biji karet dengan metode penekanan mekanis. Dari hasil melalui penelitian ini dapat diketahui variabel optimal dalam minyak biji karet dengan metode penekanan mekanis dan juga informasi data rendemen, yield, densitas, viskositas nilai bilangan asam dan nilai bilangan penyabunan minyak yang dihasilkan berdasarkan variasi ukuran partikel material dan temperatur pemanasan awal.

\section{METODOLOG}

Biji Karet (Hevea brasiliensis Muell. Arg) diperoleh dari perkebunan karet di kota Semarang. Bahan untuk mengetahui rendemen 
dan yield minyak biji karet, meliputi aquadest, etanol, $\mathrm{KOH}$, indikator PP dan $\mathrm{HCL}$ bahan-bahan kimia lain diperoleh dari CV. Jurus Maju Semarang. Analisa produk, meliputi penghitungan rendemen, penentuan kadar air minyak, analisa densitas, analisa viskositas, analisa angka asam dan analisa angka penyabunan, dilakukan di Laboratoraium Proses Pengolahan Pangan, Universitas Diponegoro.

\section{Persiapan Pembuatan Minyak Biji Karet dari Biji Karet Dengan Menggunakan Metode Screw Pressing}

1. Pretreatment bahan baku, Biji karet dipilih yang masih utuh dan tidak rapuh dipisahkan dari cabang-cabang dan pengotor-pengotor. Biji karet yang telah dibersihkan dikupas kulitnya kemudian timbang biji karet 200 gram sebanyak 3 kali. Setelah itu dihancurkan sesuai dengan variabel yang ditentukan, Biji yang telah dihancurkan tersebut ditempatkan di atas 3 buah nampan dan dipanaskan di dalam oven dengan variabel suhu yang ditentukan.

2. Tahap pengepresan, Biji karet yang telah dipanaskan tersebut kemudian dipres dengan alat screw press dengan suhu dan kecepatan putar 200 rpm. Apabila di dalam minyak terdapat pengotor maka minyak tersebut disaring terlebih dahulu sebelum dianalisa. Tabel 5 menyajikan minyak biji karet yang dihasilkan akan diselidiki kondisi optimal variabel yang digunakan dalam penelitian ini.

Tabel 5. Variabel Ekstraksi Minyak Biji Karet dengan Mesin Screw Press

\begin{tabular}{cll}
\hline Percobaan ke- & Ukuran Partikel & $\begin{array}{c}\text { Suhu } \\
\text { Pemanasan } \\
\text { Awal }\left({ }^{\circ} \mathrm{C}\right)\end{array}$ \\
\hline 1 & $10 \mathrm{~mm}( \pm 1 \mathrm{~mm})$ & 50 \\
2 & $10 \mathrm{~mm}( \pm 1 \mathrm{~mm})$ & 60 \\
3 & $10 \mathrm{~mm}( \pm 1 \mathrm{~mm})$ & 70 \\
4 & $5 \mathrm{~mm} \pm 1 \mathrm{~mm})$ & 50 \\
5 & $5 \mathrm{~mm}( \pm 1 \mathrm{~mm})$ & 60 \\
6 & $5 \mathrm{~mm}( \pm 1 \mathrm{~mm})$ & 70 \\
7 & 100 mesh & 50 \\
8 & 100 mesh & 60 \\
9 & 100 mesh & 70 \\
\hline
\end{tabular}

\section{Penghitungan Rendemen}

Dengan menimbang bahan yang akan dimasukkan ke dalam alat screw press, menimbang minyak yang dihasilkan dari proses pengepresan, dan menghitung rendemen dengan rumus:

$$
\text { \%rendemen }=\frac{A}{B} \times 100 \%
$$

Keterangan:

$\mathrm{A}=$ massa minyak yang terekstrak ( $\mathrm{gr}$ )

$B=$ massa sampel yang dimasukkan dalam alat pres (gr)

\section{Penentuan Kadar Air Minyak}

Dengan menimbang sampel minyak sebanyak 200 gram, masukkan ke dalam oven pada suhu $104-106^{\circ} \mathrm{C}$ selama 30 menit, keluarkan dari oven kemudian dinginkan pada desikator pada suhu kamar, kemudian ditimbang dan catat berat sampel minyak, dan menghitung berat kadar air pada minyak. Dengan rumus :

$$
\text { \%kadar air yang menguap }=\frac{A-B}{A} \times 100 \%
$$

Keterangan :

$A=$ berat sampel awal

$B=$ berat sampel akhir

\section{Analisa Densitas}

Dengan menimbang piknometer yang kering dan bersih, mencatat bobot piknometer kosong tersebut, piknometer diisi dengan aquadest dan ditutup hingga meluap dan tidak ada gelembung udara, lalu piknometer dibersihkan dengan tisu dan ditimbang bobot piknometer dan isinya, mencatat bobot piknometer dan air, mengulangi poin 3 sampai 3 untuk sampel minyak karet, dan menghitung densitas dengan rumus:

Keterangan:

$$
D_{T}=\frac{W^{\prime}-W}{W^{\prime \prime}}
$$

$\mathrm{D}_{\mathrm{T}}=$ densitas sampel minyak pada suhu $\mathrm{T}(\mathrm{gr} / \mathrm{ml})$

$\mathrm{W}=$ berat piknometer kosong ( $\mathrm{gr}$ )

$\mathrm{W}^{\prime}=$ berat piknometer yang berisi sampel $(\mathrm{gr})$

$W^{\prime \prime}=$ berat air pada suhu $25^{\circ} \mathrm{C}(\mathrm{gr})$

\section{Analisa Viskositas}

Dengan memasukkan air ke dalam Viskometer Ostwald, sedot cairan dengan bola karet hingga melewati garis batas atas, 
menghitung waktu alir zat cair dari garis batas atas hingga garis batas bawah, mencatat waktu yang butuhkan tersebut, mengulangi poin 1 sampai 3 untuk sampel minyak biji karet, dan menghitung viskositas dengan rumus:

$$
\frac{\eta_{1}}{\eta_{2}}=\frac{d_{1} t_{1}}{d_{2} t_{2}}
$$

\section{Keterangan:}

$\eta_{1}=$ viskositas zat cair 1 ( $\mathrm{gr} / \mathrm{cm}^{3}$. det $)$

$\eta_{2}=$ viskositas zat cair $2\left(\mathrm{gr} / \mathrm{cm}^{3}\right.$. det $)$

$\mathrm{d}_{1}=$ densitas zat cair $1\left(\mathrm{gr} / \mathrm{cm}^{3}\right)$

$\mathrm{d}_{2}=$ densitas zat cair $2\left(\mathrm{gr} / \mathrm{cm}^{3}\right)$

$\mathrm{t}_{1} \quad=$ waktu alir zat cair 1 (detik)

$\mathrm{t}_{2} \quad=$ waktu alir zat cair 2 (detik)

\section{Analisa Angka Asam}

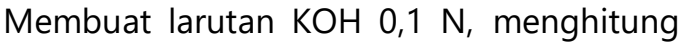
jumlah padatan $\mathrm{KOH}$ yang dibutuhkan untuk membuat $\mathrm{KOH} 0,1 \mathrm{~N}$ sebanyak $300 \mathrm{ml}$, menimbang padatan $\mathrm{KOH}$ sebanyak 4,23 gram, melarutkan padatan $\mathrm{KOH}$ di dalam beaker glass dengan sedikit air, memasukkan larutan tersebut ke dalam labu takar $300 \mathrm{ml}$, menambahkan air hingga tanda batas dan dihomogenkan.

Penetapan harga angka asam, menimbang 4,23 gram minyak karet di dalam erlenmeyer 300 $\mathrm{ml}$, menambahkan $30 \mathrm{ml}$ etanol $70 \%$, memanaskan minyak sampai mendidih dan mencatan suhunya, mendinginkan minyak tersebut dan menggojognya untuk melarutkan asam lemak bebasnya, menambahkan indikator PP sebanyak 3 tetes pada keadaan suhu dingin, mentitrasi dengan $\mathrm{KOH} 0,1 \mathrm{~N}$ hingga titik akhir titrasi (merah muda), mencatat kebutuhan volume $\mathrm{KOH}$, setelah TAT tercapai (perubahan warna menjadi merah muda), dan menghitung harga bilangan asam dengan rumus:

$$
\mathrm{AV}=\frac{56,1 \times \mathrm{T} \times \mathrm{V}}{\mathrm{m}}
$$

\section{Keterangan:}

$\mathrm{AV}=$ acid value / angka asam ( $\mathrm{gr} \mathrm{KOH} / \mathrm{gr}$ sampel)

$\mathrm{T}=$ normalitas $\mathrm{KOH}(\mathrm{N})$

$\mathrm{V}$ = volume $\mathrm{KOH}$ yang digunakan untuk titrasi (ml)

$\mathrm{m}=$ jumlah sampel yang digunakan ( $\mathrm{gr}$ )

$56,1=$ bobot molekul $\mathrm{KOH}$

\section{Analisa Angka Penyabunan}

Membuat larutan $\mathrm{HCl}$, mengambil $\mathrm{HCl} 2,75$ $\mathrm{ml}$ masukkan dalam labu takar $150 \mathrm{ml}$, menambahkan aquadest sampai tanda batas, menggojog hingga homogen, dan memasukkannya dalam buret untuk titrasi penentuan angka penyabunan.

Penetapan harga angka penyabunan, menimbang 4,23 gr minyak biji karet, lalu memasukkannya ke dalam erlenmeyer, menambahkan $\mathrm{KOH} 25 \mathrm{ml}$, memanaskan larutan sampai mendidih dan mencatat suhunya, mendinginkan larutan, setelah dingin menambahkan indikator PP sebanyak 2 tetes pada larutan tersebut, menitrasi dengan larutan $\mathrm{HCl} \mathrm{0,5}$ $\mathrm{N}$ melalui buret, mencatat kebutuhan volume $\mathrm{HCl}$ setelah TAT tercapai yaitu terjadi perubahan warna dari putih keruh menjadi merah muda, menghitung angka penyabunan dengan rumus :

Angka Penyabunan $=$

\section{$56,1 \times \mathrm{N} \mathrm{HCl} \times$ ( titrasi blanko - titrasi contoh) beratsampel $(g r)$}

Membuat larutan blanko, yaitu dengan mengambil $3 \mathrm{ml}$ aquadest, lalu memasukkannya dalam erlenmeyer, menambahkan $25 \mathrm{ml}$ larutan $\mathrm{KOH}$, memanaskan sampai mendidih, lalu mendinginkannya, menambahkan 2 tetes indikator PP, menitrasi dengan larutan standar 0,5 $\mathrm{N} \mathrm{HCl}$ melalui buret, mencatat kebutuhan $\mathrm{HCl}$ setelah TAT tercapai yaitu terbentuk warna dari merah jambu menjadi putih kebiruan, dan melakukan percobaan masing - masing dua kali.

\section{HASIL DAN PEMBAHASAN}

\section{Hasil Minyak Biji Karet}

Praktikum pembuatan minyak biji karet dilakukan dengan menggunakan alat Screw Press. Biji karet ditimbang dengan masing-masing berat biji karet setiap variabel sebanyak 200 gram sebanyak 9 kali. Guna mendapatkan minyak biji karet, biji karet ukurannya diperkecil menjadi 10 $\mathrm{mm}( \pm 1 \mathrm{~mm})$ untuk 3 variabel, $5 \mathrm{~mm}( \pm 1 \mathrm{~mm})$ untuk 3 variabel dan 100 mesh untuk 3 variabel kemudian dilakukan pemanasan awal 
menggunakan oven dengan suhu $50^{\circ} \mathrm{C}, 60^{\circ} \mathrm{C}$, dan $70^{\circ} \mathrm{C}$. Praktikum dilakukan dalam 9 variabel menggunakan screw press dengan variabel tetap pada suhu pemanas $40^{\circ} \mathrm{C}$ dan variabel kecepatan putar ulir sebesar $220 \mathrm{rpm}$. Biji karet yang sudah kering di press menggunakan alat Screw Press dan minyak biji karet yang diperoleh diambil dan ditimbang berat minyak yang didapat. Hasil minyak biji karet yang diperoleh dianalisa \% rendemen, densitas, viskositas, \% kadar air, angka asam, dan angka penyabunan.

Berdasarkan hasil pengamatan yang dilakukan, variabel 9 (ukuran material 100 mesh dan suhu pemanasan awal $70^{\circ} \mathrm{C}$ ) memperoleh persentase rendemen minyak terbanyak yaitu $10,11 \%$. Hal ini dikarenakan biji karet dengan ukuran yang lebih kecil menghasilkan persentase rendemen minyak yang lebih banyak, dimana pengecilan ukuran bertujuan untuk melukai jaringan dan sel, memperluas permukaan kontak dan memperpendek jarak difusi minyak. Selain itu juga faktor suhu pemanasan awal mempengaruhi persentase rendemen minyak yang dihasilkan karena semakin tinggi suhu pemanasan, semakin rendah kekentalan minyak sehingga minyak lebih mudah keluar dari dalam bahan. Menurut penelitian sebelumnya, bobot jenis minyak biji karet pada $25^{\circ} \mathrm{C}$ ada pada range $0,91-0,92 \mathrm{gr} / \mathrm{ml}$. Pada hasil pengamatan, densitas minyak biji karet yang dihasilkan terdapat perbedaan yang tidak begitu signifikan yaitu pada range 0,911-0,927 $\mathrm{gr} / \mathrm{ml}$. Berat jenis minyak dipengaruhi oleh derajat ketidakjenuhan minyak dan berat molekul ratarata asam lemak penyusunnya. Berat jenis minyak naik dengan naiknya derajat ketidakjenuhan minyak, tetapi turun apabila berat molekul ratarata asam lemak penyusunnya naik.

Viskositas atau kekentalan minyak biji karet hasil percobaan ada pada range 28,487-39,395 cp. Semakin tinggi suhu maka semakin rendah viskositas minyak yang dihasilkan sehingga minyak menjadi lebih mudah keluar dari dalam bahan. Kadar air pada minyak biji karet belum memenuhi standard yang ditetapkan untuk penggunaan biodiesel yaitu berada pada range 0,2-1,2 \%. Sedangkan besarnya kadar air yang ditetapkan untuk memenuhi penggunaan biodiesel sebesar maksimal 0,05 \%. Hal ini dikarenakan perlakuan pemanasan awal pada biji karet yang relatif singkat yaitu 10 menit dengan variasi suhu $50^{\circ} \mathrm{C}, 60^{\circ} \mathrm{C}$ dan $70^{\circ} \mathrm{C}$.

Menurut penelitian sebelumnya angka asam dan angka penyabunan minyak biji karet ada pada range 17,08-28,47 dan 187,6-191,4. Untuk angka asam minyak biji karet yang dihasilkan sudah sesuai yaitu 20,7-25,94. Namun untuk angka penyabunan minyak biji karet masih ada yang tidak sesuai yaitu 186,64-190,93 tetapi masih dalam batas toleran. Angka asam dan angka penyabunan akan semakin meningkat apabila disimpan pada suhu tinggi.

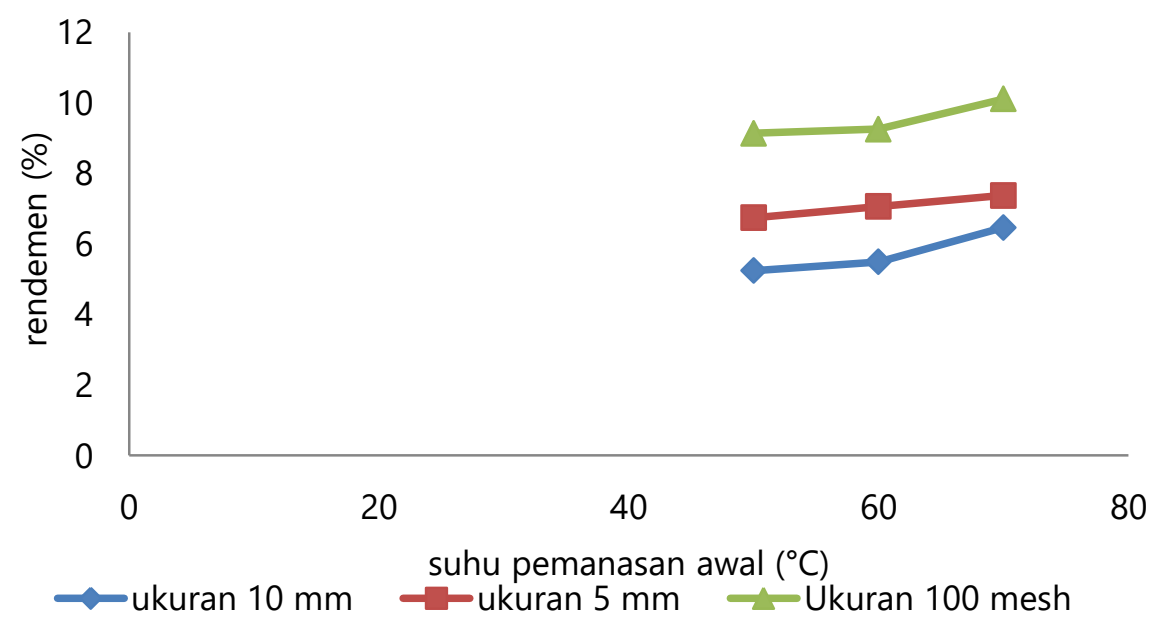

Gambar 1. Grafik Perbandingan Perolehan Persentase Rendemen terhadap Suhu Pemanasan Awal 
Berdasarkan grafik diatas diperoleh perbandingan persentase rendemen minyak biji karet yang dihasilkan. Persentase rendemen minyak biji karet dengan ukuran material 100 mesh memperoleh hasil yang lebih banyak dibandingkan minyak biji karet dengan ukuran material $10 \mathrm{~mm}$ dan $5 \mathrm{~mm}$. Hal ini dikarenakan biji karet dengan ukuran yang lebih kecil menghasilkan persentase rendemen minyak yang lebih banyak, dimana pengecilan ukuran bertujuan untuk melukai jaringan dan sel, memperluas permukaan kontak dan memperpendek jarak difusi minyak.

Hasil perolehan minyak untuk masing masing ukuran material mengalami kenaikan seiring dengan variasi suhu pemanasan awal yaitu $50^{\circ} \mathrm{C}, 60^{\circ} \mathrm{C}$ dan $70^{\circ} \mathrm{C}$ Hal ini dikarenakan suhu pada masing masing biji karet mengalami kenaikan maka viskositas minyak menjadi lebih rendah sehingga minyak menjadi lebih mudah keluar. Menurut Ketaren (1986), adanya perlakuan panas pada biji menyebabkan protein yang terdapat di dalam biji terkoagulasi (menggumpal), dan menyebabkan pecahnya emulsi antara minyak dan protein sehingga memudahkan minyak mengalir keluar, sedangkan protein tetap tertinggal di dalam bungkil. Selain itu banyaknya minyak atau lemak yang dapat diekstraksi tergantung dari lamanya pengempaan, tekanan yang diberikan dan kandungan minyak dalam bahan asal.

Berdasarkan Gambar 2. menunjukan bahwa perbandingan viskositas dan densitas pada minyak biji karet terhadap variasi suhu pemanasan awal, dimana variasi suhu pemanasan awal yang digunakan $50^{\circ} \mathrm{C}, 60^{\circ} \mathrm{C}$ dan $70^{\circ} \mathrm{C}$. Pada praktikum ini viskositas yang dihasilkan ada pada range 28,487-39,395 cp. Semakin tinggi suhu maka semakin rendah viskositas minyak yang dihasilkan sehingga minyak menjadi lebih mudah keluar dari dalam bahan. Sedangkan densitas yang dihasilkan ada pada range 0,911-0,927 gr/ml. Berat jenis minyak dipengaruhi oleh derajat ketidakjenuhan minyak dan berat molekul rata-rata asam lemak penyusunnya. Berat jenis minyak naik dengan naiknya derajat ketidakjenuhan minyak, tetapi turun apabila berat molekul rata-rata asam lemak penyusunnya naik.

Berdasarkan Gambar 3 menunjukan bahwa perbandingan persentase kadar air pada minyak biji karet terhadap variasi suhu pemanasan awal, dimana variasi suhu pemanasan awal $50^{\circ} \mathrm{C}, 60^{\circ} \mathrm{C}$ dan $70^{\circ} \mathrm{C}$. Adanya perlakuan pemanasan awal pada ekstraksi minyak biji karet menentukan kandungan air pada minyak biji karet. Pada grafik menunjukan semakin tinggi suhu pemanasan awal maka semakin sedikit kandungan air yang terdapat pada minyak biji karet. Pada praktikum ini persentase kadar air terendah terdapat pada variasi suhu pemanasan awal $70^{\circ} \mathrm{C}$ dan variasi ukuran material 100 mesh yaitu $0,2 \%$. Sedangkan untuk pemanfaatan minyak biji karet sebagai bahan baku pembuatan biodiesel mempunyai standard maksimal kadar air 0,05\%. Hal ini dikarenakan waktu pemanasan awal yang relatif singkat yaitu 10 menit sehingga kadar air yang teruapkan pada biji karet tidak optimal.

Berdasarkan Gambar 4, variasi suhu pemanasan awal $50^{\circ} \mathrm{C}, 60^{\circ} \mathrm{C}$ dan $70^{\circ} \mathrm{C}$ dengan ukuran bahan $50 \mathrm{~mm}$ maupun $100 \mathrm{~mm}$ diperoleh angka asam yang semakin naik. Angka asam minyak menggambarkan banyaknya asam lemak bebas. Semakin tinggi angka asam, semakin tinggi pula kandungan asam lemak bebas dalam sampel tersebut. Nilai Angka asam dapat digunakan untuk menentukan kualitas minyak, semakin tinggi angka asam yang dikandung dalam minyak, maka semakin tinggi tingkat kerusakan minyak (Ketaren, 1986). Berdasarkan jurnal, semakin rendah angka asam maka mutu minyak akan semakin baik.

Asam lemak bebas secara alami akan terbentuk saat minyak keluar dari dalam membran sel. Asam lemak bebas ini akan meningkat akibat terjadinya reaksi hidrolisis selama proses pengambilan maupun penyimpanan minyak. Reaksi hidrolisis terjadi akibat reaksi kimia, pemanasan, proses fisika atau reaksi enzimatis. Hidrolisis minyak menghasilkan gliserol dan asam lemak bebas yang mudah teroksidasi. Jadi semakin tinggi suhu, angka asam yang diperoleh semakin tinggi pula. Namun, angka asam hasil percobaan tersebut masih sesuai dengan penelitian sebelumnya yaitu $20,7-23,25$. 


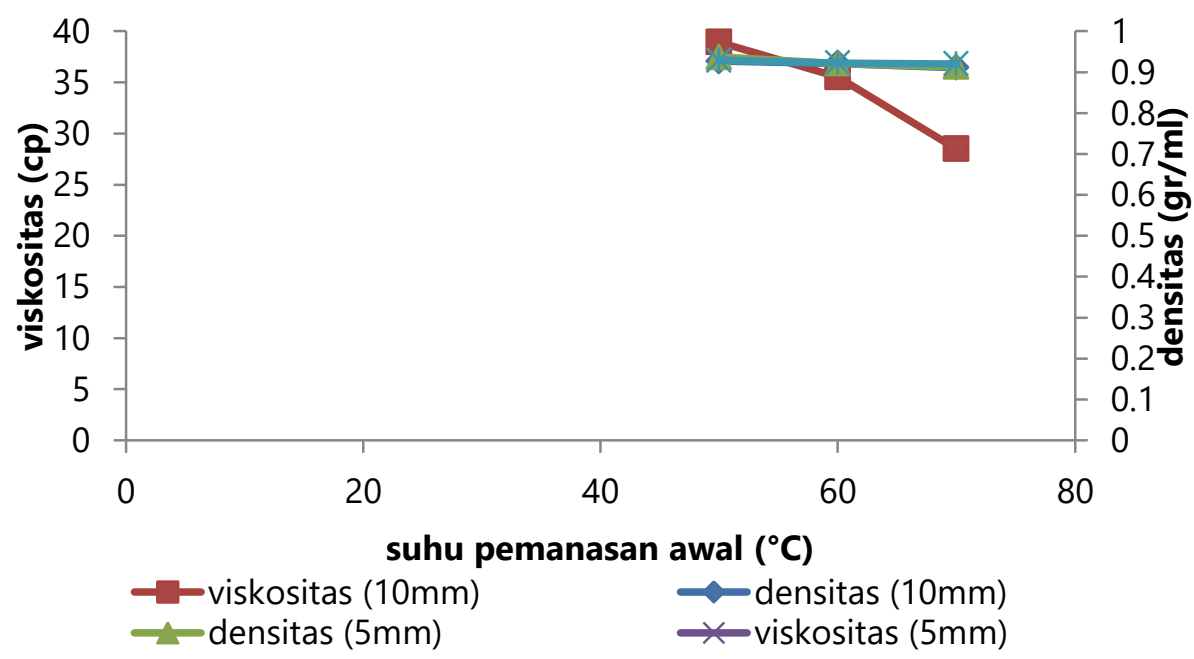

Gambar 2. Grafik Perbandingan Viskositas dan Densitas terhadap Suhu Pemanasan Awal

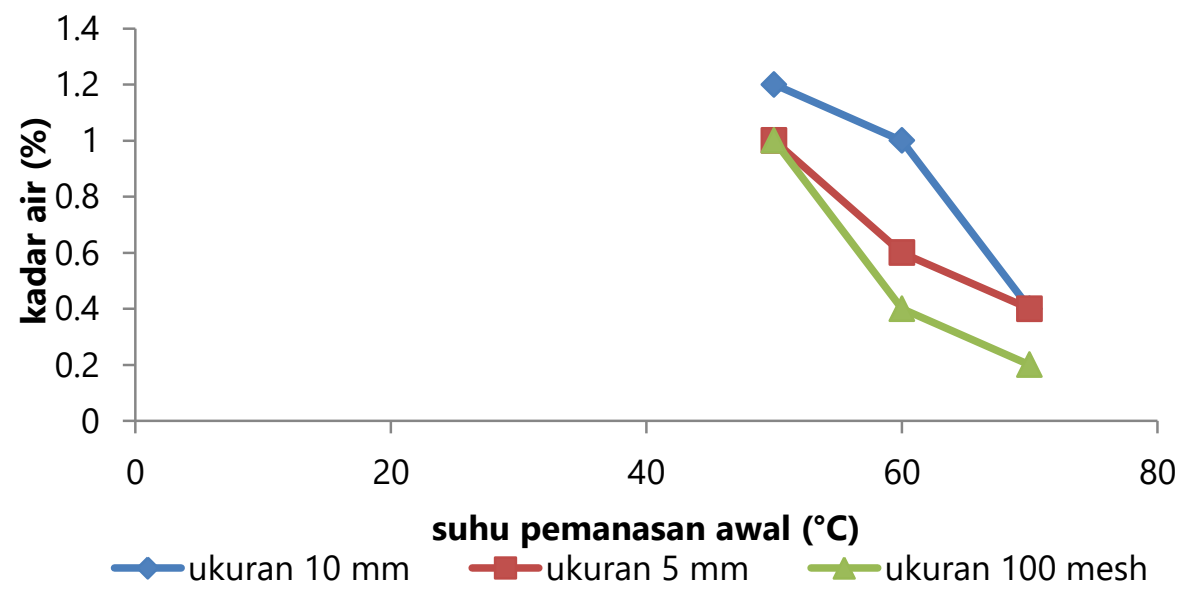

Gambar 3. Grafik Perbandingan Persentase Kadar Air tehadap Suhu Pemanasan Awal

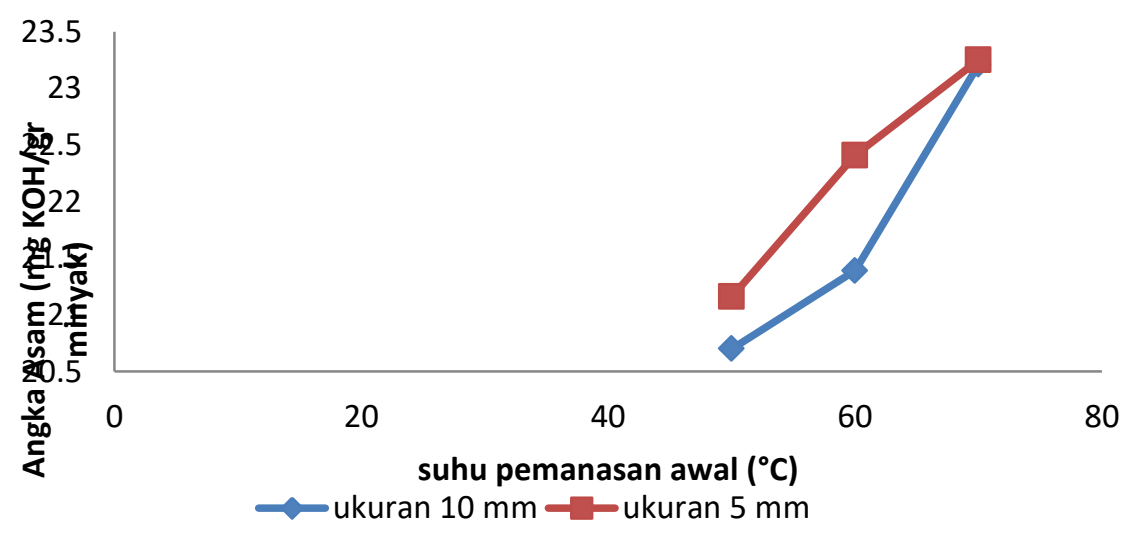

Gambar 4. Grafik Perbandingan Angka Asam terhadap Suhu Pemanasan Awal 


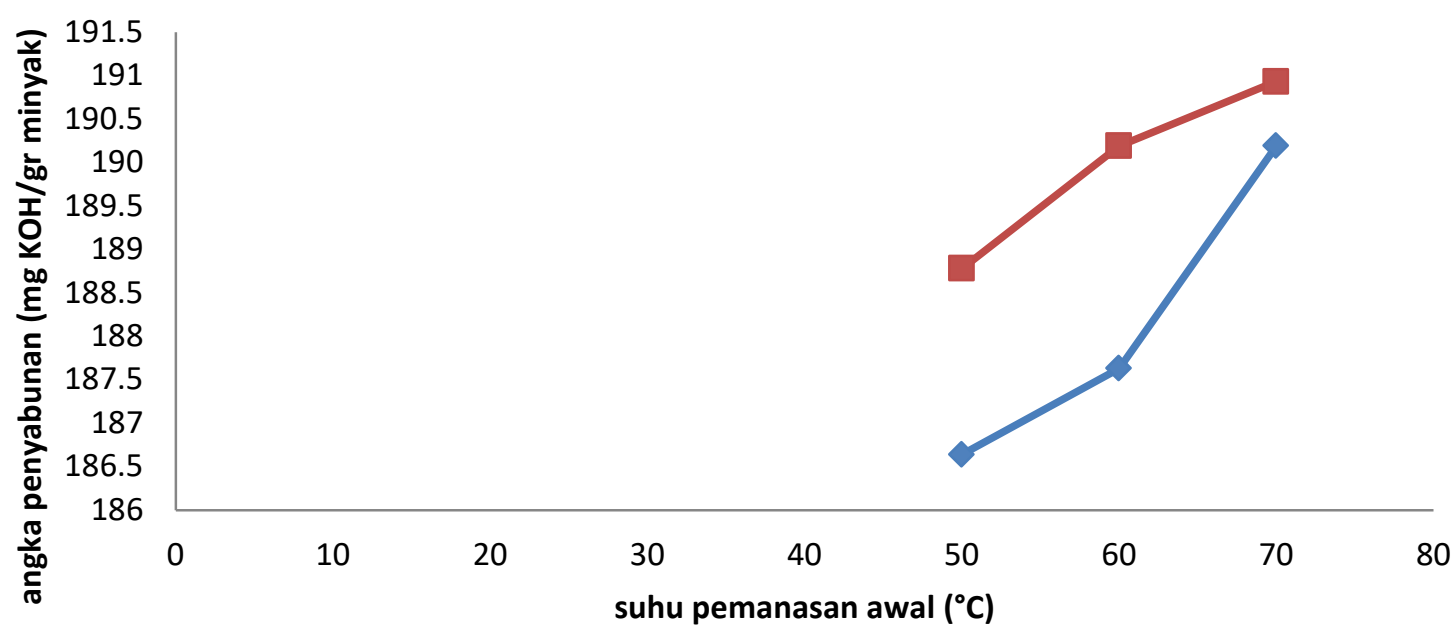

-ukuran $10 \mathrm{~mm} \quad-$ ukuran $5 \mathrm{~mm}$

Gambar 5. Grafik Perbandingan Angka Penyabunan terhadap Suhu Pemanasan Awal

\section{Perbandingan Angka Penyabunan terhadap Suhu Pemanasan Awal}

Berdasarkan Gambar 5, didapat hasil yang mengalami kenaikan angka penyabunan pada variabel minyak biji karet dengan variasi ukuran bahan $50 \mathrm{~mm}$ dan $100 \mathrm{~mm}$. Angka penyabunan yang diperoleh dapat dikatakan masih dalam batas toleran yaitu antara 186,64-190,93. Angka penyabunan menunjukkan seberapa banyak basa yang dibutuhkan untuk menyabunkan 1 gram minyak. Selain itu, angka penyabunan dapat menunjukkan berat molekul suatu sampel, sampel dengan berat molekul yang rendah akan memiliki angka penyabunan yang lebih tinggi jika dibandingkan dengan sampel dengan berat molekul yang lebih tinggi (Ketaren, 1986). Angka penyabunan yang tinggi dapat digunakan sebagai indikator kerusakan minyak.

\section{KESIMPULAN}

Karet (Hevea brasiliensis Muell. Arg) merupakan salah satu hasil pertanian yang banyak menunjang perekonomian Negara. Selain menghasilkan lateks, perkebunan karet juga menghasilkan biji karet yang belum termanfaatkan secara optimum. Dengan melihat tingginya kandungan minyak di dalam daging biji karet yakni sebesar 45.63\% (Yuliani, 2013) maka minyak tersebut sangat potensial untuk dimanfaatkan.
Berdasarkan hasil pengamatan yang dilakukan, variabel 9 (ukuran material \pm 100 mesh dan suhu pemanasan awal $70^{\circ} \mathrm{C}$ ) memperoleh persentase rendemen minyak terbanyak yaitu $10,11 \%$. Densitas minyak biji karet yang diperoleh antara 0,911-0,927 gr/ml. Viskositas minyak biji karet yang diperoleh antara 28,487-39,395 cp. Kadar air pada minyak biji karet yang diperoleh antara 0,2-1,2 \%. Angka asam minyak biji karet berada pada range 20,7-25,94. Angka penyabunan minyak biji karet ada diantara 186,64-190,93.

Dari hasil yang diperoleh, berdasarkan hasil praktikum dapat disimpulkan bahwa semakin kecil ukuran biji karet dan semakin tinggi suhu pemanasan awal maka persentase rendemen minyak biji karet semakin banyak. Densitas dan viskositas minyak biji karet semakin turun dengan adanya kenaikan suhu pemanasan awal. Angka asam dan angka penyabunan semakin naik dengan adanya kenaikan suhu pemanasan awal.

\section{DAFTAR PUSTAKA}

Larrañaga, M.D., Lewis, R.J. \& Lewis, R.A., 2016. Hawley's condensed chemical dictionary. John Wiley \& Sons.

Ikwuagwu, O.E., Ononogobu, I.C. \& Njoku. O.U., 2000. Production of biodiesel using rubber [Hevea brasiliensis] seed oil. Ind Crops. Prod. $12: 57-62$. 
Ketaren, S., 1986. Minyak dan Lemak Pangan, Edisi 1. Penerbit Universitas Indonesia (UI Press).

Setyawardhani, D.A., Distantina, S., Sulistyo, H. \& Rahayu, S.S., 2007, Separating Fatty Acids from Rubber Seed Oil by Multi Stages Hydrolisis. Regional Symposium of Chemical Engineering, Yogyakarta.

Setyawardhani, D.A., Distantina, S., Henfiana, H. \& Dewi, A.S., 2010, Pembuatan Biodiesel Dari Asam Lemak Jenuh Minyak Biji Karet. Prosiding Seminar Rekayasa Kimia Dan Proses 2010, Teknik Kimia UNDIP, Semarang.

Siahaan, S., Setyaningsih, D., \& Hariyadi. 2011, Potensi Pemanfaatan Biji Karet (Hevea
Brasiliansis Muell.Arg) Sebagai Sumber Energi Alternatif Biokerosin, Jurnal Teknologi Industri Pertanian. 19(3):145-151.

Swern, D. Bailey's. 1964. Industrial Oil and Fat Product. New York: Interscience Publ.

Yuliani, F., Primasari, M., Rachmaniah, O., dan Rachimoellah, M. 2013. Pengaruh Katalis Asam (H2SO4) dan Suhu Reaksi pada Reaksi Esterifikasi Minyak Biji Karet (Hevea brasiliensis) menjadi Biodiesel, Jurnal Teknik Kimia. 3(1):171-177. 